\title{
Leadership and Self-Control among all India Inter University Men and Women Netball Players
}

\author{
Aejaz Hassan ${ }^{1 *}$, PV Shelvam² and Mohammad Ami N Wani ${ }^{3}$ \\ ${ }^{1}$ Research Scholar of Physical Education and Sports Sciences, Annamalai University, India \\ ${ }^{2}$ Department of Physical Education \& Sports Sciences, Annamalai University, India \\ ${ }^{3}$ Department of Psychology, Annamalai University, India
}

Submission: September 14, 2017; Published: October 12, 2017

*Corresponding author: Aejaz Hassan, PhD Research Scholar of Physical Education and Sports Sciences Annamalai University, Tamil Nadu, India, Email: aejazhassan28@gmail.com

\begin{abstract}
Leadership (Ld) is the ability to direct and control the attitude or actions of others. This is especially true when this person exhibits such influence on a group. High Leadership (Ld) individuals usually occupy such positions in a group that commands a certain authority or potential for controlling the behaviour of this group. Low scoring individuals are undependable, obstructive and prefer to be sound followers. They are group dependent and impatient and are likely to escape when faced with responsibility. Self Control may be treated as the ability to bind anxiety. High scoring individuals generally have strong control over emotional life and behaviour in general. The high Self Control person shows socially approved character responses, behaviour control, persistence, foresight, considerateness of others and conscientiousness.

Low Self Control (Sc) is major contributor to the anxiety pattern and serves as important signaling the individual's inability to keep his/her emotions in order. To achieve the purpose of the study, 264 men and women netball players who took part in "All India Inter University netball Championship" held at Punjab University Chandigarh in the year 2015-2016 were selected as population. To assess Leadership (Ld) and SelfControl (Sc) of the players, Multi Dimensional Assessment of Personality (MAP) series was administrated for all 264 Netball players, out of which 214 netball players scored 1-6 in Validity Index; these 214 Netball players were selected as subjects for this study. Further these 214 netball players are divided into two equal groups on the basis of gender (men and women) between the age group of 18 to 26 years.

Leadership (Ld) and Self Control (Sc) scores were analyzed by t- test. Results revealed that there is significant difference between mean scores of Leadership (Ld) and Self-Control (Sc) among men and women netball players.
\end{abstract}

Keywords: Leadership; Self- control; Gender; MAPS and Netball players

Abbreviations: MAP: Multi Dimensional Assessment of Personality; LD: Leadership

\section{Introduction}

Personality reveals the psychological make-up of an individual through his behaviour. In fact, it the quality of a person's total behaviour. Personality is a dynamic and continuous process of learning in which the individual acquires the typical modes of responses. The word personality is used to subsume all the factors, inherited or acquired, which make up an individual. It the total sum of what one is (his psychological make-up), one's typical response patterns (to adjust in the environment or how one responds to the world around him), and behaviour patterns how one behaves differently in different situations Singh [1].

Personality refers to the characteristics patterns of the behaviour and ways of thinking that determine a person's adjustment to his environment. Personality can also be defined as individual's characteristics, thoughts, emotional responses, and behaviours that are comparatively stable over time and across circumstances. Personality is also defined as an individually unique, consistent pattern of behaviour and psychological attributes that over time and across situations Wani [2]. Personality is the set of characteristics and inner tendencies that determine those traits that are common and those that differ in behaviour (thoughts, feelings and emotions) of persons that have sort of continuity in time and that may not be easily understood in terms of the immediate situation alone Maddi [3].

Personology is the study of personality which personologists think as the underlying, relatively stable, psychological structures and processes that organize human experiences and also a person's actions and reaction to the environment Lazarus [4]. Morgan examined that athlete from various sub groups posses different personality structures such as different psychic needs 
which should be handled in personalized ways Morgen [5]. When athletes participate in many competitive sport, their underlying personality characteristics inevitably contribute to how they behave. Personality has been defined as "psychological qualities that contribute to an individual's enduring and distinctive patterns of feeling, thinking and behaving Cervone [6].

Hampson [7], found that personality traits can Predict outcomes for individuals (e.g. happiness, health), dyads (e.g. relationship Commitment), groups (e.g. team cohesion), and society (e.g. criminal behaviour). With such a strong foundation of research evidence it is surprising that personality traits and their Contribution to athletic success has often been viewed in rather cynical and pessimistic manner Hampson [7]. Personality is normally measured using a self-report questionnaire on which respondents indicate their feelings or behaviors, yielding measurements of traits such as neuroticism, anxiety, extraversion, dominance, sensitivity, assertiveness, conscientiousness, and agreeableness. Personality either predicts or is related to many things, as well as performance motivation Judge [8]. Personality is the collection of emotional and behavioural traits that characterize a person.

That is, individual's personality is how he/she presents himself/ herself to the world. It is important for leadership effectiveness. Persons public persona is the catalyst for enrolling followers Aurther [9].

\section{Objectives}

i. To find out the Leadership quality among Men and Women Netball Players.

ii. To find out the level of Self- Control among Men and Women Netball Players.

\section{Hypotheses}

i. There would be no significant differences between all Indian inter university Men and Women netball players on the variable Leadership.

ii. There would be no significant differences between all India inter university Men and Women netball players on the variable Self Control.

\section{Psychological tool}

Multi Dimensional Assessment of Personality (MAP) series Form-A, standardized by Sanjay Vohra (2011) was used to assess the leadership qualities and self control among players. The questionnaire consists of 147 items with three alternatives in each item.

\section{Procedure}

To achieve the purpose of the present study, the investigator has selected 264 Netball players from different universities of India who took part in All India Inter University Netball championship Men and Women ( $M$ \& W) held at Punjab University Chandigarh during the year march 2016. Multi Dimensional Assessment of Personality (MAP) series developed by Sanjay Vohra was administrated to 264 samples, out of which 214 players were scored 1-6 in Validity Index (VI). The respondents were equally divided into two equal groups on the basis of gender 107 men and 107 women, between the age group of 18 to 26 years. For analysis of collected data Mean and Standard Deviation, and t-test was applied for testing the hypothesis at 0.01 level of significance.

\section{Results}

Table 1; Figure 1; Table 2; Figure 2

Table 1: Mean and standard Deviation, Standard Error Mean, Mean Difference and t-value of Respondents to their in respect Leadership Scores.

\begin{tabular}{|c|c|c|c|c|c|c|c|c|}
\hline Variable & Gender & $\mathbf{N}$ & Mean & S.D & SEM & M.D & Df & T-Value \\
\hline \multirow{2}{*}{ Leadership } & Men & 107 & 6.67 & 0.99 & 0.09 & \multirow{2}{*}{0.98} & 212 & \multirow{2}{*}{$7.57^{* *}$} \\
\cline { 2 - 9 } & Women & 107 & 5.69 & 0.90 & 0.08 & & & 212 \\
\hline
\end{tabular}

Table 2: Mean and standard Deviation, Standard Error Mean, Mean Difference and t-value of Respondents in respect to their Self control Score

\begin{tabular}{|c|c|c|c|c|c|c|c|c|}
\hline Variable & Gender & $\mathbf{N}$ & Mean & S.D & SEM & M.D & Df & T-Value \\
\hline \multirow{2}{*}{ Self Control } & Men & 107 & 6.61 & 1.06 & 0.10 & \multirow{2}{*}{0.92} & \multirow{2}{*}{112} & \multirow{2}{*}{$6.79^{* *}$} \\
\cline { 2 - 9 } & Women & 107 & 5.96 & 0.93 & 0.08 & & \\
\hline
\end{tabular}

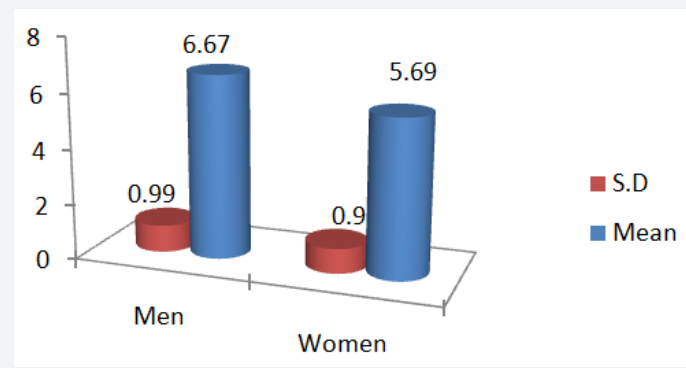

Figure 1: Graphical representation of mean and standard deviation of respondents in respect to their leadership scores

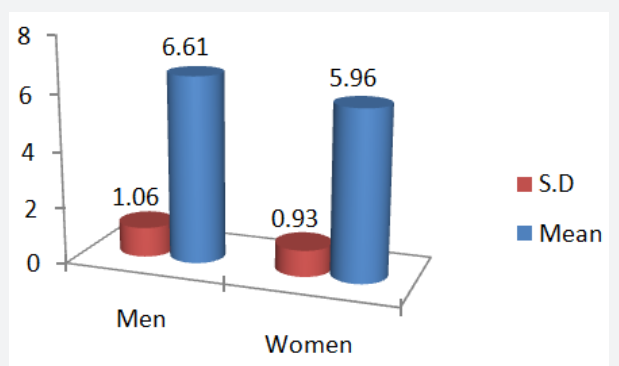

Figure 2: Graphical representation of mean and standard deviation of respondents in respect to their Self control scores 


\section{Discussion}

The present study aimed to find out the Leadership quality and self control among Men and Women Netball Players. For that purpose out of 264 Netball players, 214 players scored 1-6 in validity index; were selected as subjects for this study. Further these 214 players are divided into two equal groups on the basis of gender (men and women) between the age group of 18 to 26 years. Multi Dimensional Assessment of Personality (MAP) series Form-A, standardized by Sanjay Vohra (2011) was used to assess the leadership qualities and self control among players. The questionnaire consists of 147 items with three alternatives in each item.

The results of the present study demonstrated that there is a significant difference found between the mean scores of Men and Women Netball Players in respect to their leadership qualities, the mean, S.D, SEM, M.D and t- value of this group was found [(Men Players $(M=6.67, S . D=0.99, S E M=0.09$, Women Players (M=5.69, S.D=0.90, SEM=0.08), M.D =0.98, and $\mathrm{t}$ - value was found 7.57] respectively. The results also revealed that men players have more leadership qualities than women players, the obtained t-value was found significant at 0.01 level of significant, hence the first hypothesis is rejected.

The results of the present study also highlighted that men netball players have higher self control than women players as the mean score (6.61) of men players is more than mean scores (5.96) of women players . The S.D, SEM, and M. D of this group was found [(Men Players (S.D $=1.06, \mathrm{SEM}=0.10$, Women Players ( $\mathrm{S} . \mathrm{D}=0.93, \mathrm{SEM}=0.08)$, and M.D =0.92)] respectively. The second hypothesis is also rejected as the obtained t- value (6.79) of men and women players in respect to self control was found more that tabulation value at 0.01 level of significance therefore on the basis of the present study we can status that men have more self control than women players.

\section{Conclusion}

On the basis of the findings of the present we may conclude that men netball players have higher leadership qualities and self control than women netball players respectively.

\section{References}

1. Singh A, Bains J, Gill JS, Brar RS (2016) Essentials of physical education. ( $5^{\text {th }}$ edn), Kalyani Publishers, New Delhi, India, pp. 251.

2. Wani MA (2016) Psychology for Beginners. Mumta Publication Pvt. Ltd, J \& K, Srinagar, India, pp. 118-119.

3. Maddi SR (1976) Personality Theories. A Comparative Analysis. Honswood III, Dorsey Press, US.

4. Lazarus RS, Monat A (1979) Personality. ( $3^{\text {rd }}$ edn), Englewood Cliffs, New Jersey, US.

5. Morgen WP (1980) Personality dynamics and sports. Siunn RM (Ed.), Psychology in sports: Methods and Application. Mineapolis. Burgess Publishing Company, Minneapolis, USA.

6. Cervone D, Pervin L (2010) Personality: Theory and research, (11 ${ }^{\text {th }}$ edn), New York, USA.

7. Hampson SE (2012) Personality processes: Mechanisms by which personality traits get outside the skin. Annu Rev Psychol 63: 315-339.

8. Judge TA, Ilies R (2002) Relationship of personality to performance motivation: A meta-analytic review. J App Psychol 87(4): 797-807.

9. Aurther J (2016) Personality Development, Lotus Press Publishers \& Distributors, New Delhi, India, p. 43.

\section{Your next submission with Juniper Publishers will reach you the below assets}

- Quality Editorial service

- Swift Peer Review

- Reprints availability

- E-prints Service

- Manuscript Podcast for convenient understanding

- Global attainment for your research

- Manuscript accessibility in different formats

( Pdf, E-pub, Full Text, Audio)

- Unceasing customer service

Track the below URL for one-step submission https://juniperpublishers.com/online-submission.php 